\title{
A Dozen Lucretian Emendations
}

\author{
David Butterfield \\ Queens' College, Cambridge, CB3 9ET, UK; djb89@cam.ac.uk
}

For citation: Butterfield D. A Dozen Lucretian Emendations. Philologia Classica 2021, 16 (1), 158-169. https://doi.org/10.21638/spbu20.2021.113

In this article, twelve new emendations are offered on the text of Lucretius' De Rerum Natura. At 1.454 non tactus is proposed for the unparalleled intactus; at 2.99 et partim is suggested for the awkward pars etiam; at 2.258 quomque (late-Republican cumque) is advanced for quemque; at 2.615 the metrically problematic inuenti sint is altered to inueniantur; at 2.733 the unique use of nigrant is dispensed with by reading the expected nigra sunt; at 3.267 et tamen is made more naturally adversarial as at tamen; at 3.774 ne fess $a$ is altered to the more Lucretian defessa (reading ne for et earlier in the line); at 4.160 the unusual feminine celer (his) is altered to (his) celeris; at 4.306 (331) the difficult gerund insinuando is changed to the gerundive insinuandis; at 4.318 (343) multisque is replaced with the more idiomatic multoque; at 5.323 the stark phrase deminui debet recreari is reordered as debet deminui et recreari; finally, at 6.266 uementes is read for the otiose uenientes. The discussion proceeds on the basis of the universally accepted stemma, namely that the three Carolingian manuscripts $(\mathrm{O}, \mathrm{Q}, \mathrm{S})$ are the sole manuscripts with textual authority. The more than fifty surviving Renaissance manuscripts ultimately derive from $\mathrm{O}$, but they remain a fertile source for conjectures.

Keywords: Lucretius, textual criticism, transmission, Latin poetry, metre, Epicurean philosophy.

\section{1.454 \\ coniunctumst id quod nusquam sine permitiali \\ discidio potis est seiungi seque gregari, pondus uti saxis, calor ignist, liquor aquae ui, tactus corporibus cunctis, intactus inani.}

453 saxis $\Omega$ : saxist Wakefield ignist Bockemüller : ignibus Lambinus : ignis $\Omega$ aquae ui Timpanaro : aquis est Leo : aquae stat Postgate : aquae sic Diels : aquarum Itali : aquai $\Omega$ 454 del. Lachmann

Here Lucretius introduces the concept of properties (coniuncta $=$ Greek $\sigma \nu \mu \beta \varepsilon \beta \eta \kappa o ́ \tau \alpha)$, qualities which cannot be separated from the entities that possess them. Critical focus has fallen primarily on line 453, where the transmitted genitives ignis and aquai have resisted conversion to datives, in parallel to saxis, corporibus and inani (cf. also 449-450 his coni-

(C) St. Petersburg State University, 2021 
uncta duabus | rebus). ${ }^{1}$ But 454 presents its own oddity: intactus is deployed here - and here alone in both the poem and Latin literature as a whole - as a noun, which must bear the meaning 'intangibility. ${ }^{2}$ For Lambinus $(1570,52)$ the unparalleled intactus was a 'mira compositio'; for Lachmann $(1850,40)$ it was quite incredible: 'intactus recto casu, ut pro substantivo sit, Latine dici non potest.' He argued that nouns formed from the privative prefix in- and the verbal supine are restricted to use in the ablative: iniussu, incultu, inconsultu, inuocatu etc., alongside adverbial forms of the kind immerito, inopinato, intestato, indebito. This unique deployment of a nominative noun intactus was thus dismissed as an impossible invention, however neat its parallelism to tactus. ${ }^{3}$ As a result, Lachmann deleted 454, attributing it to the work of his frequent nemesis, the interpolator philosophus. ${ }^{4}$ But the motivation for such an insertion is hard to apprehend, and the language is otherwise Lucretian. In his review of Lachmann's edition, Spengel $(1851,783)$ defended the authenticity of 454 by replacing intactus with the substantive intactile. Although it is true that Lucretius, and only he, used the pair of adjectives tactilis (5.151) and intactilis (1.437), this emendation has not won subsequent support.

Perhaps we may find a better solution by looking at another binary opposition in the poem? To convey the technical business of sensation, Lucretius used (and, again, perhaps coined) the adjectival pair sensilis $(2.888,893,895,902)$ and insensilis $(2.866,870,888$, 902). However, when reaching for an opposite term to the standard noun sensus, he did not attempt the coinage ${ }^{\star}$ insensus. Since that route seemed to be linguistically barred, he instead used the idiomatic option of non as a nominal modifier, to create the negative counterpart non-sensus (2.930 scire licet gigni posse ex non sensibus sensus; 931-932 quod si forte aliquis dicet, dumtaxat oriri | posse ex non sensu sensus mutabilitate). Later in Book 1, Lucretius will use a similar route to express the concept of the non-middle: per medium, per non medium (1075). ${ }^{5}$ I therefore suggest that in 454 Lucretius introduced the most natural opposing term to tactus, i. e. non tactus. The corruption of non to in would have been easy in context, and perhaps abetted by the following inani.

\section{2.99}

quod quoniam constat, nimirum nulla quies est reddita corporibus primis per inane profundum,

${ }^{1}$ It is impossible to construe aquai as a dative. Just as in other poets, the search in Lucretius for datives in -ai is fruitless: patriai at 1.41, summai at 1.953 and fugai at 1.1047 are genitives. Curiously, Charisius $(16,22-27$ B.) mistakenly cites aulai medio (Verg. Aen. 3.354), intus aquai (Verg. Aen. 7.464) and <terrai> frugiferai (Enn. Ann. 510 Sk.) as his examples, although they are unanimously agreed to be genitives. While it is true that a dative in -ai did exist in Early Latin (as Quintilian noted at Inst. 1.7.18), its spondaic prosody is most improbable: Nigidius Figulus, cited by Aulus Gellius (13.26.4), regarded it as monosyllabic form, whereas Garrod (1914) made the case for a hypothetical iambic scansion. For further support of the conjecture aquae ui, see Timpanaro (1947) and Deufert (2018) 32-34.

2 TLL VII. 1 2069.55: 'status rei, quae tangi non potest.'

${ }^{3}$ Elsewhere in the poem intactus is adjectival, meaning 'untouched' $(3.813=5.358,6.1060)$, or (if Bentley's deletion of the verse, followed by Deufert's Teubner edition (2019), is resisted) 'intangible' at 1.334. No support is given for the noun intactus by the two parallel Epicurean terms (reported by Sext. Emp. Adv.

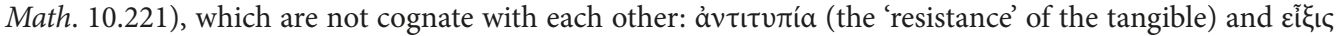
(the 'yielding' of the intangible).

4 After the dismissal of line 454, the construction of 453 was subsequently normalised to genitives by introducing saxist alongside ignis and aquai.

${ }^{5}$ Although this licence is not common in high-register Latin, elsewhere in philosophical literature Cicero reports Zeno's concept of non-body as non corpus (Ac. 1.39). 
sed magis adsiduo uarioque exercita motu

partim interuallis magnis confulta resultant,

pars etiam breuibus spatiis uexantur ab ictu.

98 confulta $\Omega$ : conflicta $F$ : compulsa Cippellarius : contusa Lambinus : conlata Reid

The incessant motion of atoms is subdivided in the last two lines between two types of concilia: those that allow for the wide-ranging movement of atoms after their initial compression (98), and those that force their atoms to move around within a tighter network. The subsequent lines (100-108) clarify that this distinction describes substances like air and sunlight on the one hand, and solids like stone and iron on the other. But the syntactic division between these two groups (partim... pars...) is most unusual: while Lucretius used both partim... partim... and pars... pars... in succession, ${ }^{6}$ their juxtaposition together is without parallel. Even those who wish to argue that such synesis is acceptable, on the basis that it is attested in other Latin authors, ${ }^{7}$ must acknowledge another oddity: in all other Lucretian cases, pars takes a singular verb, despite the subject referenced most often being plural in number. ${ }^{8}$ That this was Lucretian style is confirmed by the four cases $(4.568,570,5.288,6.1168)$ where the singular verb is guaranteed by metre. ${ }^{9}$ Lucretius should therefore have written uexatur for uexantur in 99 - but this change of number mid-sentence would create an unwelcome imbalance.

Real balance could be restored to these lines in two ways, either by reading (i) partim in 99, or (ii) pars in 98. The latter option may at first seem the better course, because of the existence of verse-initial pars etiam at 4.946 and $5.255 .{ }^{10}$ But the alteration introduces its own problems: exercita of 97 would no longer understand an implied corpora from corporibus in 96, but pars as its delayed subject. However, the singular exercita would lead even more strongly to reading singular verbs in both 98 and 99, contrary to the manuscripts. What is more, the text that immediately follows this sentence makes clear enough that corpora is in fact the plural subject: et quaecumque magis condenso conciliatu| exiguis interuallis conuecta resultant (100-101). ${ }^{11}$ Corpora, explicitly stated in 104, is in actuality the subject throughout 97-108. We are left, then, with option (i) of reading partim in $99 .{ }^{12}$ Strong support for this change is given by the fact that atomic corpora are likewise divided into two groups by partim at 1.483-484 and 4.54-57. ${ }^{13}$ Alteration of pars alone would introduce the collocation partim

6 partim... partim: 1.483-484, 4.55-57, 736-737, 917-918, 5.266-268 (partim quod), 6.20-23 (partim quod), 1058-1059, 1208-1211 (partim... nonnulli... partim); pars... pars: 4.568-571, 944-947 (x3), $5.251-256$.

7 See further LHS II. 436.

8 pars horum maxima (4.464: tricks of the eye that deceive the mind), pars uocum (4.568: of the various sounds that emanate from an utterance; likewise 570), pars glebarum (5.255: of clods of soil), pars horum (5.288: of the sun's rays), pars [hominum] (5.1025), pars hominum (6.1168).

9 At 5.1025, transmitted as sed bona magnaque pars seruabat foedera casti, most editors reject Marullus' alteration to seruabant, preferring instead the Renaissance emendation to adverbial caste.

10 At 4.946, pars etiam appears as the third element after pars and et... pars; at 5.255, pars etiam opens a new sentence, introducing a different part of the land from pars terrai nonnulla (251).

11 The combination of exiguis interuallis with conuecta resultant reveals that uexantur ab ictu of 99 balances both confulta (whether or not this hapax is retained or substituted with another conjectured participle) and resultant of 98 .

12 partim is frequently used in close succession, and in all but one case (3.917-918, where the uis animae is subdivided) with plural verbs.

13 1.483-484 corpora sunt porro partim primordia rerum, | partim concilio quae constant principiorum; 4.54-57 (see below). 
etiam, ${ }^{14}$ a pairing not otherwise found in Lucretius but common in Cicero. While partim etiam is intelligible as an extension of the corpora adsiduo uarioque exercita motu (97), the sense would flow more idiomatically without any additional adverb. It may therefore be that Lucretius simply wrote et partim, a pairing that opens the Lucretian line elsewhere (4.918, $5.952,1083)$, most notably in a very similar context at 4.54-57:

principio quoniam mittunt in rebus apertis

corpora res multae, partim diffusa solute,

robora ceu fumum mittunt ignesque uaporem,

et partim contexta magis condensaque, ...

Perhaps the elements par, et, tim were confused when the line was copied as a unit, or perhaps the loss of et (easy at the beginning of the verse) led to the simple repair of the line's faulty metre, with partim inevitably placed first, as in $98 .^{15}$

\section{2.258}

unde est haec, inquam, fatis auolsa uoluntas,

per quam progredimur quo ducit quemque uoluptas,

declinamus item motus nec tempore certo

nec regione loci certa, sed ubi ipsa tulit mens? (2.257-260)

257 uoluntas Marullus : uoluptas $\Omega$ : potestas Lachmann 258 uoluptas $A B F$ : uoluntas $\Omega$

Lines 257-258 are well known for the requisite reversal of the near-homophonous nouns transmitted at the end of each verse. But a further corruption may lurk in 258: while quemque is perfectly intelligible as the object of ducit ('where pleasure leads each [of us: cf. progredimur and declinamus]'), greater force would be given by reading quomque (the Lucretian orthography for cumque): 'to wherever pleasure leads'. In seventeen other places Lucretius splits quicumque and cognate adverbs with tmesis of cumque in the fifth foot. ${ }^{16}$ Of the six other cases of adverbial quocumque, ${ }^{17}$ the closest in sense is 6.299 quocumque tulit uis (understanding the object fulmen). For ducere without a stated object, we may compare $4.680-682 ;^{18}$ but we need only look at the close of 260 in the very sentence under discussion to see the ellipse of an object: sed ubi ipsa tulit mens. The corruption of sepa-

14 The elision would not be greatly different from inferiorem etiam (4.937), mobilitatem etiam (6.341) and paulatim et (5.535)

${ }^{15}$ I have wondered whether a defence could be made for reading partim iam: it is a Lucretian idiom when introducing new instances or examples to deploy iam, apparently without any obvious temporal force: 2.426 sunt etiam quae iam nec leuia iure putantur | esse, 431 fecula iam quo de genere est inulaeque sapores, 447 in quo iam genere in primis adamantina saxa, 3.481 et iam cetera de genere hoc quaecumque sequuntur (cf. 2.171, 744), 4.87 sunt igitur iam formarum uestigia certa, 185 in quo iam genere est solis lux et uapor eius, 6.1080 cetera iam quam multa licet reperire! At 4.116 iam appears alongside partim: primum animalia sunt iam partim tantula. However, as with the other potential alteration to partim tam breuibus, the line is really more hindered than helped by any such adverb.

$161.510,873,2.21,404,865,3.550,1075,4.737,5.289,6.19,85,389,738,867,876,1004,1033$.

$173.51,4.166,424,5.285,6.299,882$.

18 At 2.172 (ipsaque deducit dux uitae dia uoluptas) mortalis is understood as the object from the previous line. 
rated quomque to quemque would have been very easy in context, not least because of the common confusion of $e$ and $o .^{19}$

\section{2.615}

Gallos attribuunt quia, numen qui uiolarint

Matris et ingrati genitoribus inuenti sint, significare uolunt indignos esse putandos, uiuam progeniem qui in oras luminis edant.

sint Odo : sunt $\Omega$

Amid his colourful depiction of the Magna Mater cult, Lucretius explains why the eunuch Galli have a special role: it is because those who have violated the Great Mother's godhead and been found to be ungrateful to their parents do not deserve to propagate their own offspring. ${ }^{20}$ But it is the metre, not the matter, of line 615 that requires comment here. Its spondaic close inuenti sint may seem a perfectly possible variation for a poet such as Lucretius. However, the actual evidence offers little support: the De rerum natura contains 32 lines exhibiting a fifth-foot spondee, i. e. one every 230 lines. The great majority $(26=81 \%)$ of these cases involve a word of four syllables (including those ending with enclitic-que); ${ }^{21}$ five of the remaining six involve the close pairing of a monosyllable before a trisyllable (1.1077 cum uenere 2.475 ac mansuescat, 3.191 est natura, 417 et mortalis) or a trisyllabic equivalent (2.309 sint in-motu). ${ }^{22}$ The one remaining exception is 2.615 above, where inuenti $\operatorname{sint}^{23}$ closes the line.

Aware of this genuine oddity, Lachmann suggested reversing these two words to sint inuenti (with genitoribus suffering sigmatic ecthlipsis). Although no editor has adopted the change, ${ }^{24}$ it was simply untrue of Bailey (1947 II. 904) to dismiss it as 'gratuitous'. Since there is nothing to obstruct the combination of the true perfect uiolarint with a generalised present, ${ }^{25}$ perhaps inueniantur could be read. The whole passage summarises the cult's practices in a present-day context: devotees give (attribuunt) the Magna Mater eunuchs, because they wish (uolunt) to signal (significare) that those who have violated (uiolarint) her majesty and are found (inueniantur) to be unworthy of their parents are (esse) to be deemed (putandos) unworthy of issuing (edant) new offspring. Verbal forms (including participles, gerunds and gerundives) consisting of five syllables close the line 116 times

19 See 1.932, 2.301, 928, 4.577, 581, 696, 879, 5.654, 675, 906, 997, 1068, 1150, 6.13, 51, 589, 1040.

20 I follow the interpretation of Benario (1973), which takes et to be a genuine conjunction, rather than serving an explanatory role (as if $i d$ est).

$211.60,64,586,616,991,1116,2.295,302,397,1053,1147,3.198,249,253,545,907,963,4.125,187$, $198,975,978,5.190,425,1156,1265$. Forms of the type dissoluuntur $(1.764,3.706)$, dissoluantur (1.519, 3.330), dissoluensque (1.559), dissoluique (3.815, 5.360), dissoluitque (6.446) and exsoluatur (1.811), achieve a five-syllabled close by the regular Lucretian licence of diaeresis. Despite any precise parallel, I suspect that Lucretius invoked this licence with inuoluentes at 5.971.

22 Lachmann suggested rewriting omnia cum rerum primordia sint in motu as omnia cum sint in motu primordia rerum: it is fair to wonder why Lucretius did not write the line thus, given that primordia in $75 \%$ (55/71) of its other occurrences falls in the fifth foot, with primordia rerum closing the line 24 times.

${ }^{23}$ Editors adopt the necessary subjunctive first conjectured (c.1460) in Milan Ambros. E 125 sup. by Pietro Odo.

24 The closest call came with Flores, who recorded in his apparatus $(2002,180)$ 'fort. recte'.

25 The allusion to this passage in Paulus' epitome of Festus echoes this true perfect s.v. Galli (95 M.): alii putant, ideo eos sibi genitalia incidere, quia violaverint numen patris matrisve, ne possint ipsi fieri parentes. 
elsewhere in the poem, including the cognate inuenientes at $1.736 .{ }^{26}$ If this suggestion is correct, the corruption to inuenti sint would have been easily catalysed by the preceding perfect uiolarint, which stands directly above in 614 .

\section{2.733}

nunc age dicta meo dulci quaesita labore percipe, ne forte haec albis ex alba rearis principiis esse, ante oculos quae candida cernis, aut ea quae nigrant nigro de semine nata.

Lucretius advances his argument that atoms are colourless: white and black objects, for instance, are not made of white and black atoms. In 733 we find the verb nigrant, which must bear the sense of 'are black'. Yet in its one other occurrence in Classical Latin some 150 years later (Stat. Siluae 2.6.82-83 atros $\mid$ nigrasset planctu... lacertos) it has the expected transitive, causative sense of 'make black.27 The minor emendation to nigrent, i. e. the archaic verb nigreo, would introduce the more expected form of a stative, intransitive verb, but in its only two occurrences the verb possesses the inchoative sense of 'become black', as if nigresco. ${ }^{28}$ The question therefore arises, could Lucretius have written a closer parallel to the preceding alba and candida, viz nigra sunt ${ }^{29}$ The pyrrhic scansion of nigra, attested in poets of the subsequent generation, ${ }^{30}$ can be supported by Lucretius' practice with analogous words: alongside the long initial syllable for forms of migrare $(2.775,3.7575 .830)$, he scans remigrant with a short second syllable at 2.966. As for the artistic juxtaposition of two different scansions of nigr- in the same line, we may compare 4.1222: quae patribus patres tradunt a stirpe profecta. ${ }^{31}$ Given the prevalence of the adjective nigrans in other Classical authors, the slip from nigra sunt to nigrant could have been easily made.

\section{3.267}

quod genus in quouis animantum uiscere uolgo est odor et quidam color et sapor, et tamen ex his omnibus est unum perfectum corporis augmen...

267 color $R$ : calor $\Omega$

26 Since such a list has not been recorded before, I give the passages here to spare others the tedium: $1.113,180,251,291,317,390,391,400,501,519,535,736,764,811,818,876,909,939,968,996,1026,1043$, $1085,2.26,42,145,234,346,450,506,531,551,568,684,792,914,922,948,981,1008,1074,1138,1162$, $3.26,71,148,210,248,330,352,364,478,485,601,613,639,671,689,692,698,706,722,729,738,780,782$, $796,864,937,1028,4.14,51,70,259,271,278,306,628,668,697,776,1030,1202,5.15,44,73,140,167,289$, $316,332,342,376,384,428,533,971,1320,1426,1453,6.112,164,189,424,648,653,802,889,955,1032$, $1040,1066,1133,1263,1277,1286$ (the last line of the poem as transmitted).

27 Tertullian, in c.207 AD, used the verb metaphorically: nigrati ignorantiae tenebris (Adv. Marc. 4.8); Probus later defined nigro as nigrum facio (GLK IV 202,7).

28 Pac. 88 R., Acc. 260 R.

29 The gloss of Lambinus ad loc. $(1570,171)$ is, in fact, 'nigra sunt.'

30 Verg. Aen. 8.353 (nigrantem), Prop. 4.6 .83 (nigras), Ov. Her. 2.72 (nigri), Man. 1.222 (nigris).

31 Cf. also sacra repeated with different prosody in 5.1163-1164. 
Lucretius here draws an analogy for how the commingling of heat, air, wind and the nameless fourth element creates the sensation of life in the human soul (269-272): despite the separate presence of a given scent, colour and flavour in the flesh of living creatures, Lucretius argues that one complete body nevertheless grows from them. Given the contrast in play, did he follow the two instances of et in 267, which join the flesh's three distinct elements, with $\underline{e t}$ tamen? If so, the sequence of sound est... et... et... et... ex... gives the line a misleadingly unifying balance. ${ }^{32}$ We may also note that in the sixteen other instances of the collocation, et tamen is restricted to the first foot of the line. ${ }^{33}$ More probable in this context would be for Lucretius to mark the contrast with at tamen, a pairing that he uses mid-sentence earlier in the book (3.172); ${ }^{34}$ at is deployed both mid-sentence and mid-verse nine times elsewhere. ${ }^{35}$ The corruption to et would have been particularly easy after the two preceding instances of the conjunction.

\section{3.774}

quidue [sc. uis animi ex 771] foras sibi uolt membris exire senectis?

an metuit conclusa manere in corpore putri,

et domus aetatis spatio ne fessa uetusto

obruat?

$(3.772-775)$

Lucretius here asks, with impatient sarcasm, why the spirit - if it really were immortal - would wish to leave an elderly body at the point of death. In 773 he turns to ask whether it 'fears to remain trapped in a rotting body and (fears) that its house, wearied by the aged span of time, may collapse?' As commentators note, this requires that metuit govern first an infinitive, then a dependent ne clause, an awkward combination not paralleled elsewhere. In fact, the sentence expresses only one fear - that the spirit may suffer from bodily collapse if it stays too long - not two: et thus has no purpose. A neater form in which Lucretius may have written the lines is offered by comparing the last clause of Book 2: nec tenet omnia paulatim tabescere et ire | ad capulum spatio aetatis defessa uetusto. The phrase spatio defessa uetusto again closes the line at 5.827, where the earth is compared to a woman beyond childbearing age. If $n e$ fess a represents a corruption of defess $a,{ }^{36}$ the verse could have begun with the expected ne: ${ }^{37}$ 'or does the house fear to remain trapped in a rotting body, in case the house..... ${ }^{38}$

32 In the two other cases of five-fold alliteration in a line (1.200 non potuit, pedibus qui pontum per uada possent; 5.94 tris species tam dissimilis, tria talia texta), both verses convey a single unified thought.

$331.1050,2.331,898,3.267,923,4.473,612,811,1149,5.213,476,768,1125,1177,1421,6.603$.

34 si minus offendit uitam uis horrida teli $\mid$ ossibus ac neruis disclusis intus adacta, | at tamen insequitur languor terraeque petitus | suauis (3.170-173). The collocation recurs elsewhere with words interposed: at non esse tamen (2.459), at locus ille tamen (3.536), at tepefacta tamen (6.322).

352.74 (with contra), 388, 392 (with contra), 3.312, 406, 1018, 4.473, 611, 6.1171.

36 defessus occurs six times elsewhere $(2.1174,5.827,1129,1145,6.1162,1177)$, fessus five times (1.257, $2.1038,3.458,4.848,5.308)$.

37 While Lucretius does use neu alongside neue (as at 2.414, 6.599), its deployment here would again give the unwelcome sense of two distinct fears. It is perhaps worth repeating 'Kenney's First Law', that any opening monosyllable of Latin verse can be corrupted into any other monosyllable.

${ }^{38}$ For the most recent defence of the unusual intransitive (or, more probably, elliptically transitive) use of obruat, see Deufert (2018) 176-177. 


\section{4.160}

ergo multa breui spatio simulacra genuntur,

ut merito celer his rebus dicatur origo.

159 genuntur Lambinus : geruntur $\Omega$

The feminine celer has parallels in early Latin (Liv. Andr. 40 Bl. celer hasta; Enn. Ann. $420 \mathrm{Sk}$. acer hiemps). Yet, although there is no other nominative form of celer to compare, Lucretius draws a clear distinction between masculine acer (3.503, 4.304, 420, 6.128, $658,1184,1212)$ and feminine acris $(1.246,3.65,477,741)$. The expected feminine celeris would thus be in line with Lucretius' treatment of this type of adjective, and it would restore a perceptible caesura to the third foot. Half a millennium ago, Pius (1511) read celeris rebus, but some deictic marker to refer to the particular simulacra under discussion is clearly required. ${ }^{39}$ Perhaps Lucretius wrote his celeris rebus? For the regular separation of his from rebus, see 1.449, 2.44, 184, 216, 581, 891, 1089, 3.28, 4.865, 5.16, 480, 6.423, 543, 647; merito is similarly elided at 2.698 (before ex), 3.715 (in-) and 953 (in-). Whether his and celeris were accidentally transposed so that his stood alongside rebus, or celeris was miswritten as celer his, the transmitted text would have been the natural outcome.

\section{9. $4.306(331)$}

praeterea splendor quicumque est acer adurit saepe oculos ideo quod semina possidet ignis multa, dolorem oculis quae gignunt insinuando. (4.304-306 (329-331))

Lucretius here recounts how bright objects cause pain to the eyes because of their seeds of fire. In 306, oculis can be read as the dative indirect object of dolorem gignunt. But insinuando is left unusually weak and isolated as a closing word, which must be understood not only intransitively but also without any supporting prepositional construction. The observation of Godwin $(1986,113)$ will hardly do: 'insinuando is poised at the end of the sentence, suggesting the end of the process.' Elsewhere in Lucretius, insinuare displays a remarkable range of constructions: it is transitive in five instances, taking the accusative of the object that enters (2.436 sese, 6.860 suum aestum) or the object that is entered (1.409 latebras, 5.73 pectora), or both simultaneously (1.116 se, pecudes); in addition, there are 19 cases of the verb used personally in the passive, describing what has (been) inserted, often with an almost middle force $(1.113,2.684,3.671,689,698,722,729,738,780,782$, $4.525,1030,6.234,277,355$ bis, $802,955,1031)$; there is also one instance of the impersonal gerundive (5.44). This leaves four intransitive instances, three $(6.89=385,778)$ qualified by per, and one used absolutely: 3.485-486 paulo si durior insinuarit | causa. On the basis of this last case, editors have retained insinuando as transmitted, but its syntactical and rhythmic separation is appreciably more stark. Can anything be done to incorporate it more closely with the preceding text? While it is true that writing oculos for the dative oculis would provide a natural object for insinuando, the resultant commingling of verbs and their objects is not Lucretian. But for a poet who often made productive use of the

39 This problem was apprehended by Cartault $(1898,56)$, but his suggestion of celeris rei introduces an unwelcome singular number for $r e s$. 
gerundive, it may be a neater route to retain the transmitted oculis and modify it with insinuandis. ${ }^{40}$ For this instrumental use of the gerundive we may compare 4.1209-1210: et commiscendo cum semine forte uirilem | femina uim uicit. A scribe could easily have normalised the word into the commoner form and syntax of the gerund.

\section{0. $4.318(343)$}

e tenebris autem quae sunt in luce tuemur propterea quia, cum propior caliginis aer ater init oculos prior et possedit apertos, insequitur candens confestim lucidus aer, qui quasi purgat eos ac nigras discutit umbras aeris illius; nam multis partibus hic est mobilior multisque minutior et mage pollens.

Lucretius describes how we can see objects in the light when we ourselves are in the dark: bright air is able to dispel the black air that reached our eyes first, because it is faster (mobilior), made of smaller elements (minutior) and more powerful (mage pollens). The first of these adjectives is modified by 'many degrees' (multis partibus), the last by a mere 'more' (mage, the byform of magis used by Lucretius thrice elsewhere: 4.81, 756, 5.1203). The intervening comparative minutior is preceded by multis, which must be construed as understanding partibus from 317. Editors have been content with this reading, but a more balanced sequence would be achieved by reading Lucretius' typical intensifier of a comparative - multo, deployed in this role 27 times elsewhere. That Lucretius may have preferred such triple variation here is suggested by the one other passage where he used the unusual combination multis partibus, 1.734-735: hic tamen et supra quod diximus inferiores | partibus egregie multis multoque minores. Multoque would have easily been corrupted under the influence of the multis that comes both before and above it.

\section{5.323}

nam quodcumque alias ex se res auget alitque,

deminui debet, recreari cum recipit res. (5.322-323)

323 deminui $O$ : diminui $Q$

The striking hendiadys debet, recreari is all the more striking when contrasted with its parallel phrase auget alitque in the preceding verse. Lucretius' one other analogous pair of asyndetic verbs is found at 4.1199: subat ardet; ${ }^{41}$ of nouns, we may cite the pair pro-

${ }^{40}$ It should be noted, of course, that Lucretius had a particular penchant for gerundival phrases in the dative plural: 1.24 scribendis uersibus, 184 augendis rebus, 203-204 rebus... gignundis, 547 rebus reparandis, 552 frangendis rebus, 577-578 frangendis... corporibus, 707 gignundis... rebus, 746-747 secandis | corporibus, 844 corporibus... secandis, 2.855 gignundis rebus, 5.181 gignundis rebus.

${ }^{41}$ Richter $(1974,94-95)$ plausibly suggested that ardet fell into the text as a gloss of the rare subat (of animals 'on heat'), ousting a word such as ignis (a genitive dependent on abundans, although Lucretius elsewhere construes abundo with the ablative); an adverb such as intus may be more probable. At 1.680-681 we find three verbs with one connective: quaedam discedere abire | atque alia adtribui, although Bockemüller's $a b$ igne is worthy of consideration in lieu of abire; at 3.395, the same structure is found in concursare coire 
elia pugnas $(2.118,4.1009)$, although longer lists appear without connectives (1.663-634, $685=2.1021,1.744,2.553-554,670,726=5.441,4.458,784,1132) .{ }^{42}$ But while asyndeton is a feature of Lucretian style, it seems unusually harsh here, not least when recreari differs from deminui in carrying its own dependent clause cum recipit res. ${ }^{43}$ Unsurprisingly, the other pairs of passive infinitives in the poem exhibit the usual connection: cf. $1.661 \mathrm{om}-$ nia denseri fierique ex omnibus unum, 681 atque alia attribui mutarique ordine quaedam, 2.1069 geri debent nimirum et confieri res, 3.484 at quaecumque queunt conturbari inque pediri, 4.555 plane exaudiri discernique articulatim, 4.676 et fluere et mitti uolgo spargique putandumst, 6.922 perpetuo fluere ac mitti spargique necessest. It is fair to wonder, therefore, whether Lucretius did not write something else.

Initial possibilities emerge to be dead-ends: recrearique would give the required connective, but would demand the introduction of $u t$ for cum, a conjunction that Lucretius does not employ with a temporal sense. ${ }^{44}$ Alternatively, a gerundive recreandum (agreeing with the subject quodcumque) may give the desired sense '(which is) due to be restored', but this anticipatory usage is not Lucretian. Since both verbs are equally dependent upon debet, the simplest solution would be to insert et between them. Yet deminui et debet would unhappily separate the modal verb with its second infinitive. A more probable option is that Lucretius wrote debet deminui et recreari cum recipit res. To the reader versed in Augustan poetry, this rhythm will sound inevitably clunky. But it is worth reminding ourselves of two quirks of the Lucretian hexameter:

(i) et regularly opens the third foot (thus depriving it of any perceptible caesura): ${ }^{45}$ what is more, 64 (79\%) of the 81 cases involve the elision of the preceding word, presumably because the syllable lost in elision gives the feel of a quasi-caesura. Et stands in this position after a passive infinitive twice (3.661 tortari et, 4.400 uersari et), and after an active infinitive eleven times. ${ }^{46}$

(ii) As a self-contained opening spondee, debet reflects a rhythm that Lucretius often employed. Although he could not have written the opening words I conjecture

et dissultare. At 3.156 we have the three balanced elements caligare oculos, sonere aures, succidere artus. At 3.1013-1014 we find the sequence reges expugnant, capiuntur, proelia miscent, | tollunt clamorem. The pairing alit auget is read by some editors at 5.257, but Lambinus' alid auget (paralleling alias res auget at 5.322 ) is more probable: alit is wrongly transmitted for alid at 1.263, $407(\mathrm{Q}), 3.970,5.1456(\mathrm{Q})$. The verse 1.873 (praeterea tellus quae corpora cumque alit auget) is deleted by many editors as an interpolated variant of 1.867 (praeterea quaecumque e terra corpora crescunt); in contrast to the asydentic pair alit auget, we find a conjunction at 1.228 (alit atque auget) and 859 (auget corpus alitque).

42 At 1.455-456 seven nouns are joined in asyndeton, although the third element carries a -que.

43 It has long been observed that Lucretius owes a debt in 5.318-323 to a famous fragment of Pacuvius' Chryses (90-92 R., itself echoing Euripides' Chrysippus), which includes the asyndetic sequence of verbs animat format alit auget creat | sepelit recipitque. But since the closest verbal echo of the passage comes in auget alitque, which patently carries a connection, it would seem unwise to use Pacuvius to defend the asyndeton of 323 .

44 The two exceptions involve the combination of the clarificatory adverb semel $(1.1030,4.610)$; Lachmann's et is consequently read for $u$ t at 6.234 .

45 (An asterisk denotes elision of the preceding word) $1.129^{\star}, 55^{\star}, 58^{\star}, 162,220^{\star}, 333^{\star}, 351^{\star}, 397^{\star}$, $730,777,801^{\star}, 826^{\star}, 889^{\star}, 994^{\star}, 2.94^{\star}, 124^{\star}, 566^{\star}, 674^{\star}, 678^{\star}, 699^{\star}, 845^{\star}, 1063,1143^{\star}, 3.138^{\star}, 281^{\star}, 395^{\star}$, $435^{\star}, 534^{\star}, 609^{\star}, 629^{\star}, 635^{\star}, 640^{\star}, 661^{\star}, 681,693,696^{\star}, 743,818^{\star}, 920,4.139^{\star}, 143^{\star}, 232^{\star}, 377^{\star}, 400^{\star}, 418^{\star}$, $491,732^{\star}, 930^{\star}, 969^{\star}, 982^{\star}, 1060^{\star}, 1131^{\star}, 1174,1179^{\star}, 1214^{\star}, 1243^{*}, 5.12^{\star}, 40,115^{\star}, 262^{\star}, 363^{\star}, 375^{\star}, 417^{\star}$, $431,497,653^{\star}, 668^{\star}, 737,817^{\star}, 890^{\star}, 1317^{\star}, 6.338,410^{\star}, 539^{\star}, 619^{\star}, 858^{\star}, 1134^{\star}, 1159,1211,1269^{\star}, 1282^{\star}$. $461.220,397,994,2.124,674,3.534,818,4.139,418,982,5.558$. 
in a different order, we may consider those cases where he could have: there are 51 verses in the poem which begin with a spondaic word although it would have been metrically, grammatically and stylistically acceptable to avoid that rhythm by rearranging the opening two or three words. ${ }^{47}$ In some cases, the reason for preferring the more unusual rhythm may be emphasis (e. g. 1.66 primum Graius homo, 101 tantum religio, 473 numquam Tyndaridis); in others, it may be euphony (1.262 ludit lacte mero mentes perculsa nouellas, 4.1020 multi mortem obeunt, 6.444 uertex conradens ex aere semina nubis). In the majority of cases, however, there seems to me no reason for this less common rhythm, as with the recurrent opening debent nimirum $(1.592,2.161,340)$. A similar deployment of a spondaic finite verb can be found at 3.1060: exit saepe foras magnis ex aedibus ille. ${ }^{48}$ In the present instance, however, where Lucretius could not both write deminui debet and provide a conjunction for recreari, the natural way to open the line would have been debet deminui et recreari.

For the scribe copying in units of half-lines or full lines, debet deminui et could have been accidentally reversed to the rhythmically typical deminui debet, with the consequent loss of the homophonous syllable et.

\section{6.266}

sic igitur supera nostrum caput esse putandumst tempestatem altam. neque enim caligine tanta obruerent terras, nisi inaedificata superne multa forent multis exempto nubila sole; nec tanto possent uenientes opprimere imbri, flumina abundare ut facerent camposque natare, si non extructis foret alte nubibus aether.

266 tanto... imbri $\Omega$ : tanti... imbres Lambinus

Verse 266 has long caused editors problems: the subject of possent, modified by uenientes, is unstated but can only conceivably be 'clouds'. While nubila of 265 points to that interpretation, feminine nubes instead needs to be taken in anticipation from nubibus (268) later in the sentence, just as obruerent (264) awaits its subject in nubila (265). The line of thought is that clouds could not cause great flood damage unless the sky had them 'piled high' extructis... alte. ${ }^{49}$ Lambinus' emendation of tanto... imbri to tanti... imbres can therefore be passed over: the ablative imbri performs this same role at 1.282 and 286. In order to provide an express object for opprimere, Watt $(1990,126)$ emended uenientes to umentes,

$471.66,101,128,150,261,454,473,560,592,813,1065,2.54,161,328,340,614,617,645,875,938$, $1052,3.264,785,1060,4.352,705,871,968,991,1013,1014,1015,1018,1020,1026,1027,1104,5.129,234$, $321,393,418,429,521,804,6.1,293,444,515,1031,1178$. (At 4.743, 5.443, 691, 6.775 and 990 prepositional propter opens the line but could have been placed between the following two words that it governs.)

48 At. 6.689 Lucretius wrote tollit se ac rectis ita faucibus eicit alte, where he could have written se tollit rectisque ita faucibus eicit alte.

49 Lucretius had already used similar language for the origin of thunderbolts: fulmina gignier e crassis alteque putandumst | nubibus extructis (246-247). There is thus no need to adopt Bockemüller's alteration to the nominative extructus. 
understanding terras from $264 ;{ }^{50}$ while the earth is naturally understood as the verb's object, it is idle to specify its already moist state, let alone with a word unattested in Lucretius. In fact, 6.285-286 provide us with a clear parallel for opprimere used of burst thunderclouds without any stated object: displosa repente | opprimere ut caeli uideantur templa superne.

Still, the participial uenientes is decidedly odd: does the arrival or coming of the clouds carry sufficient relevance or force to introduce the large-scale floods that follow? How could any storm emerge from clouds that are not 'coming'? Instead, the passage's focus lies on the power that these clouds can unleash in the form of mighty downpours. Could Lucretius therefore have written uementes? It is 'violent' clouds that overpower the land with such extreme downpours. As he writes later in this book: sed uemens imber fit, ubi uementer utraque | nubila ui cumulata premuntur (517-518). The misreading of $m$ as $n i$, particularly easy in minuscule script, can be paralleled in Lucretius as in other classical authors. ${ }^{51}$ It may be added that, if Pluygers' emendation is accepted at 1.285-286 - nec ualidi possunt pontes uementis (uenientis W) aquai | uim subitam tolerare - we have an exact parallel for this slight corruption. ${ }^{52}$

\section{References}

Bailey C. (ed.) Titi Lucreti Cari De Rerum Natura Libri Sex (3 vols). Oxford, Clarendon Press, 1947.

Benario H. W. Lucretius 2.615. Classical Philology 1973, 68, 127-128.

Cartault A. La Flexion dans Lucrèce. Paris, F. Alcan, 1898.

Deufert M. Kritischer Kommentar zu Lukrezens De Rerum Natura. Berlin, De Gruyter, 2018.

Deufert M. (ed.) Titus Lucretius Carus: De Rerum Natura. Berlin, De Gruyter, 2019.

Flores E. (ed.) Titus Lucreti Carus: De Rerum Natura. Libri I-III. Naples, Bibliopolis, 2002.

Garrod H. W. Aquai in Lucretius. Classical Review 1914, 28, 264-266.

Godwin J. (ed.) Lucretius: De Rerum Natura VI. Warminster, Aris and Phillips, 1986.

Lachmann K. (ed.) In T. Lucretii Cari De Rerum Natura Libros Commentarius. Berlin, G. Reimer, 1850.

Lambinus D. (ed.) T. Lucretii Cari De Rerum Natura. Paris, ${ }^{3} 1570$.

Pluygers W. G. Io. Niv. Madvigii... Ferias Saeculares Tertias (Progr.). Leiden, 1875.

Pius J. B. (ed.) In Carum Lucretium Poetam Commentarii. Bologna, 1511.

Richter W. Textstudien zu Lukrez. Munich, Beck, 1974.

Spengel L. Review of Lachmann (1850). Gelehrte Anzeigen der K. Bayerischen Akademie der Wissenschaften $1851,96,769-783,788-792$.

Timpanaro S. Dativi in āī in Ennio ed in Lucrezio? Studi Italiani di Filologia Classica 1947, 22, 209-213.

Watt W. S. Lucretiana. Museum Helveticum, 1990, 47, 122-127.

Received: January 10, 2020

Accepted: April 15, 2021

${ }^{50}$ Lambinus' first route to correction was to suggest uiuentes or animantes, making humans the verb's object. By contrast, Godwin $(1991,114)$ tentatively suggests that the transmitted uenientes should be taken as an accusative: 'people travelling'.

${ }^{51}$ For confusion between $m$ and in, examples are provided individually by the two complete ninth-century mss: 4.710 qum $(\mathrm{O})$ for quin (corr. $\mathrm{O}^{2}$ : qur $\mathrm{Q}$ ), 5.1082 quo in $(\mathrm{Q})$ for quom $(\mathrm{O}), 6.1175$ inerrans $(\mathrm{Q})$ for mersans $(\Omega)$.

52 Pluygers 1875, 5-6. 